\title{
AGRP Gene
}

National Cancer Institute

\section{Source}

National Cancer Institute. AGRP Gene. NCI Thesaurus. Code C115166.

This gene plays a role in feeding behavior. 